研 究 報 文

\title{
コロナ放電処理によるセルロース繊維シート物性の変化
}

\author{
東京農工大学農学部応用生物科学科 佐渡 篤, 桜井邦夫*1, 大橋 隆*2 \\ 東京農工大学工学部電子情報工学科 松井 満
}

\section{Change in Physical Properties of Cellulose Fibre Sheets by Corona Discharge Treatment}

\author{
A. Sawatari, K. Sakurai and T. Ohhashi \\ Lab. of Cellulose Sci. \& Technol., Dept. of Applied Biological Sci., Faculty of \\ Agriculture, Tokyo University of Agriculture and Technology \\ M. Matsui \\ Lab. of Applied Electromagnetics, Dept. of Electronics and Information Engineering, \\ Faculty of Technology, Tokyo University of Agriculture and Technology
}

Whatman \#1 filter paper, handsheet from softwood bleached sulfate pulp (abbreviated as NBKP hereafter), handsheet from thermomechanical pulp (abbreviated as TMP hereafter) and regenerated cellulose film were treated with 401 watts $/ \mathrm{m}^{2}$ of corona discharge for the duration of 0 to $180 \mathrm{~min}$. Some changes were examined in the SEM images of the cellulose fibre sheets, in the sheet strength and in the sheet porosity by the increase in the duration of the corona treatment. The following results were obtained.

(1) The SEM images changed with the Whatman \# 1 filter paper, the handsheet from NBKP and the handsheet from TMP. That is, perfolation or boring occured in the case of the higher duration of $30 \mathrm{~min}$. and $60 \mathrm{~min}$. But, no changes occured with the regenerated cellulose film, as the duration of the corona treatment increased.

(2) The tensile index and Young's modulus of the fibre sheets decreased gradually but significantly with the increase in duration of the corona discharge treatment. At that time, the zero span tensile strength also decreased slightly. The tensile index and tensile modulus decreased also in the case of regenerated cellulose film with the increase in the duration.

(3) As the duration of corona treatment increased, the cellulose fibre sheets became more permeable. The porosity and mean pore radius obtained by the mercury intrusion method also increased with the increase in the duration. However, no changes occured in permeability with the regenerated cellulose film, even in the duration of $180 \mathrm{~min}$.

From the above-described facts, the corona-induced defects is considered to partly bring about the decrease in the cellulose fibre sheet strength.

Another mechanism should be considered further from the fact that the tensile strength and the tensile modulus decreased with the increase in the duration for the regenerated cellulose film. A certain fraction of the more microscopical framework which regists against an external force, must be degradated by the oxidation processes. Both mechanism are proposed to affect the reduction in cellulose sheet strength by the corona treatment for a long duration. At the present state, the

\footnotetext{
*1 現在, 富士ゼロックス株画像技術研究所 *2 現在, 王子油化命成紙(侏)開発研究所
} 
importance of the two mechanisms cannot be estimated for the reduction in the sheet strength.

Keywords : Corona Discharge Treatment, Mercury Intrusion Method, Air Permeability, Porosity, Mean Pore Radius, Boring, Defect, Oxidation Process

\section{1. 緒言}

紙匹に溶融ポリオレフィンを押出し塗工する場合, 紙匹のコロナ放電処理は必須の前処理であり ${ }^{1)}$, 現実 の工程で広く採用されている。このコロナ放電処理に よる紙匹の表面改質機構は未だ解明されていない2-5)。 従来からこの機構解明のための実験室規模の試みはい くつかなされているが, その放電の強さなどの条件が 一致せず, 各研究者により各地で得られたデー夕を比 較することも困難であった。それらの放電条件をまと めて表 1 に示す ${ }^{5-10)}$ 。表 1 からわかる様にそれらの放 電条件は各研究者によってそれぞれ異なり，他のデー 夕と比較出来ないことが多い。ここでは,そうしたデー 夕の比較のために放電処理を受ける側の物性变化から 処理条件を比較出来ないかと考えた。そのために, 紙 匹の主要構成成分であるセルロース繊維シートが受け る物性変化に着目することとした。そのために，バッ 千式コロナ放電処理装置を用いて 0 1 180 分にわたつ て種々の時間コロナ放電処理をおこない, 各種シート 物性の変化, つまりシートの引張り強さ, ヤング係数, 厚さ, 密度, 吸着水分, 多孔性などの変化について調 べ検討をおこなった。

\section{2. 実験}

\section{1 試料}

ワットマンNo. 1 滤紙はソックスレー抽出器を用い て 10 時間エタノール/ベンゼン混液によって抽出後, 数日間風乾してから試料とした。試料はシリカゲルを
入れた褐色プラスチック製デシチータ中に保管した。

NBKP手すき紙は市販の NBKPをPFIミルに よってろ水度 $400 \mathrm{~m} l$ C. s. f. に叮解し, 常法によって 坪量 $60 \mathrm{~g} / \mathrm{m}^{2}$ の手すき紙を得な。そのシートをワット マンNo. 1 滤紙と同様に, エ夕ノール/ベンゼン抽出 処理し風乾後保管した。

TMP 手すき紙はラジアータパイン TMP をナイア ガラビータによりろ水度 $170 \mathrm{~m} l$ C. s. f. に吒解してか ら抄造して得た。この TMP 手抄き紙はワットマン No. 1 濾紙, NBKP 手すき紙と同様に抽出し風乾後保 管した。

再生セルロースフィルムはセロファンテープ用セロ ファン（東京セロファン紙侏製 PT No. 500）を水道水 洗浄後, 蒸留水洗浄, 有機溶剂洗浄, 蒸留水洗浄して から，風乾して再生セルロースフィルムを得た。この 処理過程を詳記すると,(1) $300 \mathrm{~mm} \times 830 \mathrm{~mm}$ の大きさ に切り出したセロファンを水道水中に浸漬して水道水 を一昼夜流して洗浄する。(2)蒸留水に 2 日間浸漬する。 この間合計で蒸留水を 4 回入れ換える。(3)メ夕ノール, エ夕ノール, ベンゼン, エ夕ノール, メ夕ノール, メ 夕ノ一ル/水 $(1+1)$, ミリ $\rho$ 水, ミリ $\mathrm{Q}$ 水の順にセ口 ファンの両面にかけて洗浄する。ミリ $\rho$ 水とミリ $\mathrm{Q}$ 水 は $500 \mathrm{~m} l$ ずつ, その他の溶剤は $50 \mathrm{~m} l$ ずつ使用する。 精製水による仕上げの洗浄は特に丁寧におこなう。(4) 洗浄済セロファンの長さ力向に両端をおよそ長さ 25 $\mathrm{mm}$ ずつガラス棒に巻き付け，一様に延ばした状態で テフロンシートをコートした $240 \mathrm{~mm} \times 745 \mathrm{~mm}$ の大 きさの木枠に張り付ける。次にガラス棒の四隅に 305

Table 1 Corona discharge conditions in published studies ${ }^{5-10)}$.

\begin{tabular}{|c|c|c|c|c|c|}
\hline Researcher's Name & $\begin{array}{c}\text { Applied } \\
\text { Voltage } \\
(\mathrm{kV})\end{array}$ & $\begin{array}{c}\text { Frequency } \\
(\mathrm{Hz})\end{array}$ & $\begin{array}{c}\text { Electrode } \\
\text { Gap } \\
(\mathrm{mm})\end{array}$ & $\begin{array}{c}\text { Dielectric Layer } \\
\text { Thickness } \\
(\mathrm{mm})\end{array}$ & $\begin{array}{c}\text { Air Gap } \\
(\mathrm{mm})\end{array}$ \\
\hline M. Morita \& I. Sakata ${ }^{6}(1987)$ & 15 & 60 & 6.0 & - & - \\
\hline I. Sakata \& D. A. I. Goring ${ }^{7)}(1976)$ & 15 & 60 & 3.0 & - & - \\
\hline M. Stradal \& D. A.I.Goring ${ }^{8)}(1977)$ & 19 & 45 & - & - & - \\
\hline P. Blais, D. J. Carlsson \& D. M. Wiles ${ }^{9}(1971)$ & 25 & $0.5 \mathrm{M}$ & 31.0 & 3.0 & 25.0 \\
\hline J. F. Carley \& P. T. Kitze ${ }^{10) *}(1978)$ & - & $1.9 \mathrm{k}$ & 2.5 & 0.5 & 1.5 \\
\hline A. Sawatari \& H. Nakamura ${ }^{5)}(1992)$ & 13 & 50 & 5.2 & 3.0 & 2.2 \\
\hline
\end{tabular}

*: This mark shows continuous system. The others, that is, those with no ${ }^{*}$ mark show batch system. 
$\mathrm{g}$ の重りを吊るし, 更に $120 \mathrm{~g}$ と $170 \mathrm{~g}$ の重りを付けた クリップを全長辺にアルミニウム棒を介してほほ均等 に取付けて $20^{\circ} \mathrm{C} ， 65 \% \mathrm{RH}$ の雾囲気中で，上にカバー をかけ污れやほこりがつかない様に注意して 24 時間 乾燥させた。これらの重りや棒は乾燥中にフィルム面 にしわを生じさせない様に張力をかけるために使用し た。洗浄済みセロファンをこの乾燥用の木枠に掛けて 乾燥する模様を図 1 に示す。乾燥の終了した試料は $100 \mathrm{~mm} \times 100 \mathrm{~mm}$ 及び $100 \mathrm{~mm} \times 160 \mathrm{~mm}$ の大きさに 切り，上記と同様に保管した。

\section{2 コロナ放電処理}

本実験においては図 $2 に そ の$ 外観を示すコロナ放電 処理装置を使用した。この装置は張ら ${ }^{11)}$ が使用した装 置と基本的には類似している。IEC 電極 ${ }^{12,13)}$ 本体と しており，バッチ式で試料固定型のものである。外気 の混入を防ぐ為に, 処理部を内径 $220 \mathrm{~mm} \phi$ 容積 $8 l$ のベルジャーによって覆いチャンバーとした。この時 の電気系回路図を図 3 に示す。この装置は高電圧発生 装置としてネオントランス(最大出力電圧 $15 \mathrm{kV}, 2$ 次 側短絡時電流 $20 \mathrm{~mA}$ ) を使用し, 1 次側電圧を摺動電圧 調整器 (商品名スライダック)により変えることによっ て 2 次側電圧を調節する形式のものである。電極間の

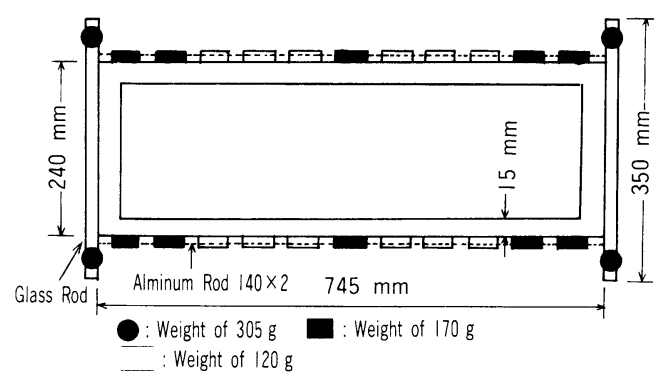

Fig. 1 Drying apparatus for regenerated cellulose film.
出力電压は $13 \mathrm{kV}$ とした。図 4 に電極構成を示す。こ の IEC 型電極は平行平板電極であり，放電を均一にす るために, 真ちゅう板電極の間に誘電体としてガラス 板を隔壁材料に用い，高電圧側（上側）のガラス板に アルミ箔をはり付けて印加電極とした。またアース側 (下側)のガラス板に試験片の四隅を両面テープにより 固定して放電した。

本実験では，放電雾囲気を酸素とした。先ず試料を 装填してから，チャンバー内を真空ポンプにより吸引 後, ボンベから酸素ガスをチャンバー内に導入し，流 量計を見ながらバルブを開閉し $80 \mathrm{ml} / \mathrm{min}$. の一定流 量にした。処理条件は周波数 $50 \mathrm{~Hz}$, 処理電圧 $13 \mathrm{kV}$, 放電出力 $4.01 \mathrm{Watt}$, 電極板面積: $1.0 \times 10^{-2} \mathrm{~m}^{2}$, 電極 板間距離: $5.2 \mathrm{~mm}$, 空隙幅: $2.2 \mathrm{~mm}$, 誘電体 (ガラ 又板) 厚さ: $3.0 \mathrm{~mm}$ の一定として室温, 大気压下, 酸 素雾囲気 (流量 $80 \mathrm{~m} l / \mathrm{min}$.) で 0 １80 分間にわたって コロナ放電をおこなった。

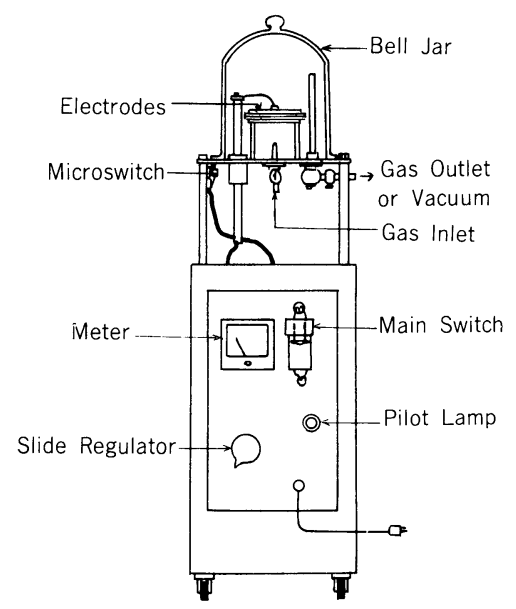

Fig. 2 External appearance of corona discharge apparatus used.

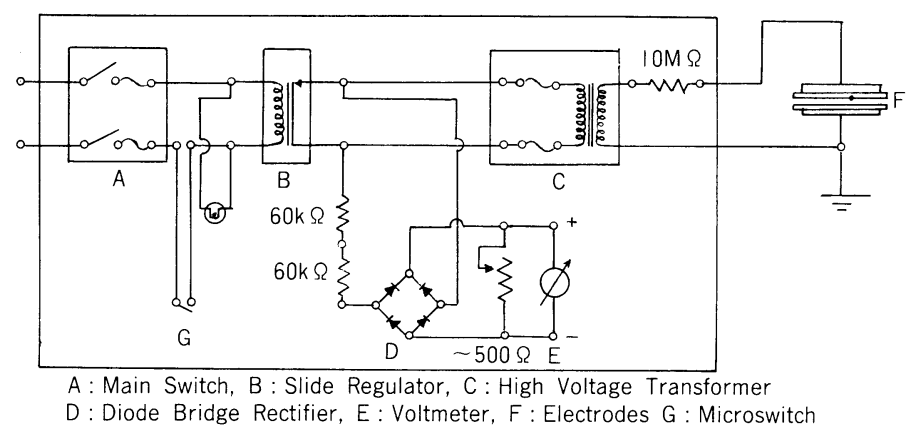

Fig. 3 Electrical circuit for corona discharge treatment system. 


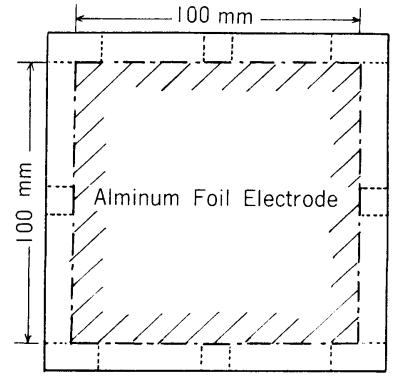

to High Voltage

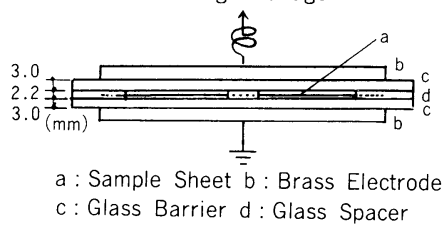

Fig. 4 Composition of electrodes.

\section{3 処理面の SEM による観察}

両面テープにより試料ホルダーに放電済みシート試 料を固定し, 試料の側端に導電性銀ペースト（ドータ イト)を塗布してから，日本電子(怢製 JFC-1100 型イオ ンスパッタリング装置により $1,200 \mathrm{~V}, 10 \mathrm{~mA}$ で 3 分 間金を蒸着した。

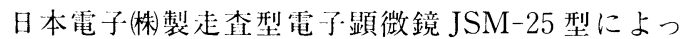
て处理面を観察した。加速電圧は $15 \mathrm{kV}$, 試料傾斜角は 0゚とした。

\section{4 シートの物理的性質}

シート試料の坪量, 厚さ, 密度は JIS-P-8118 に準じ て测定した。

\section{5 シートの引張り試験}

引張り試験は JIS-P-8113 に準じ, $20^{\circ} \mathrm{C}, 65 \% \mathrm{RH} の$ 恒温恒湿室中で東洋ボールドウィン(株製 UTM-II-20 型により, 試験つかみ間隔：100 mm, クロスへッドス ピード $10 \mathrm{~mm} / \mathrm{min}$.としておこなった。

\section{6 水銀ポロシメータによる多孔性測定}

多孔性测定のための水銀压人法ポロシメー夕は島津 製作所製ポアサイザー 9310 を使用した。水銀の表面張 力は 484.0 dynes $/ \mathrm{cm}$, 接触角は $130.0^{\circ}$ とし, 水銀の密 度は $20.0^{\circ} \mathrm{C} て ゙ ~ 13.546 \mathrm{~g} / \mathrm{c} . c$. とした。細孔直径につい ての累積曲線から，㞋入された水銀の累積量 $50 \%$ に相 当する細孔半径を読みとって中央值とした。また試験 片の体積 $\left(\mathrm{mm}^{3}\right)$ に対する累積総压入量 $\left(\mathrm{mm}^{3}\right)$ の比 をパーセント表示して空隙率とした。

\section{7 透気度の測定}

旭精工:(有)製王: 研式透父境平滑度試験機を用いて測定 した。

\section{3. 結果と考察}

\subsection{SEM による処理面の観察}

SEMによって観察する前に肉眼によってシート面 の観祭をおこなった。各シートを光に透かしてみると ワットマン濾紙とパルプ繊維からの手すき紙の場合, 処理時間が 30 分から 60 分以上になると, 未処理シ一 卜に比較して光の透過量が增えることを観察した。こ のことは，放電の進行によってシート処理面に穿孔を 生じたために起こったのではないかと考え，処理面を SEMによって観察した。その結果を図 5〜7に示す。 図において白い矢印が穿孔を示し，それらの直径は約 10 20 $\mu \mathrm{m}$ である。ワットマン No. 1 滤紙では 60 分以 上になると穿孔が認められ，NBKP 手すき紙では 30 分以上になると穿孔が認められること，そして TMP 手すき紙では 30 分から明確に穿孔が認められること を観察した。これらの穿孔は処理時間か増加すると， 孔の大きさと数が共に增加する傾向が認如られ，その 傾向は TMP 手すき紙, NBKP 手すき紙，ワットマン 滤紙の順に強かった。しかし再生セルロースフィルム については，少なくともこの実験条件及び撮影条件の 場合には穿孔を認めることは出来なかった。以上の観 察結果をまとめて表 2 に示す。門屋は紙をスパーク放 電すると紙に元来あった細孔がスパークによって広げ られるが，新たに穿孔が見られることはなく強度低下 も見られないと述べている ${ }^{14)}$ 。しかし今回の観察結果 では新たに穿孔が見られる場合もあった。

\section{2 シート物性の変化}

コロナ処理した各試料の坪量, 厚さ, 密度, 比引張 り強さ, ヤング係数, 破断までの伸び率, 水分を表 3〜7 にまとめて示す。表の中でコロナ処理時間の増大に 伴って明らかに減少を示しているのは引張り強さ, 比 引張り強さそしてヤング係数である。比引張り強さと 裂断長について四示したのが図 8 であり, ヤング係数 について図示したのが図 9 である。比引張り強さもヤ ング係数も小さい減少率であるが確実に減少すること が分る。しかもここで注目すべきことは, 再生セルロー スフィルムについてもコロナ処理の進行によって比引 張り強さとヤング係数が減少していることである。ま た，コロナ処理の進行によるゼロスバン強度の変化を 図 10 に示す。罒からコロナ処理の進行によって繊維強 度が極く僅かに減少することが分る。表 3〜7 に示す様 に密度や吸着水分の変化が大きくないこと及びX線回 折四から求㜭晶化指数の变化が小さいこと（図 11）から考えると，一つには穿孔部分の寸法の增大と 穿孔数の増加, つまり欠陥部分の寸法の増大と欠伯部 


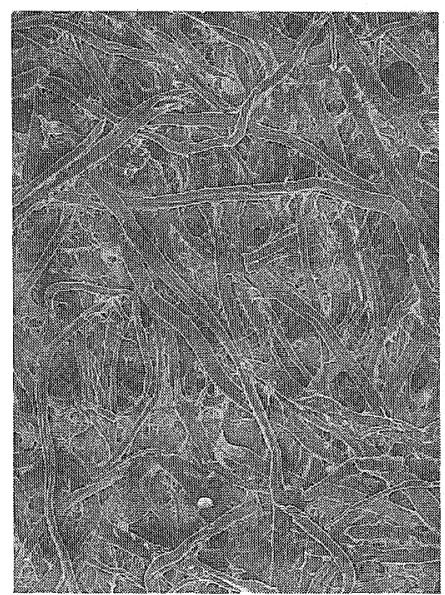

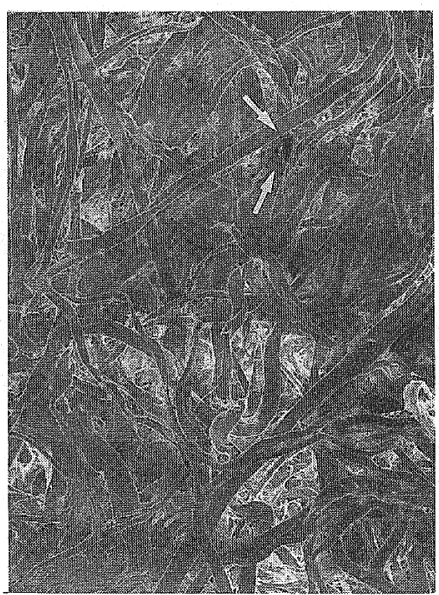

$90 \mathrm{~min}$.

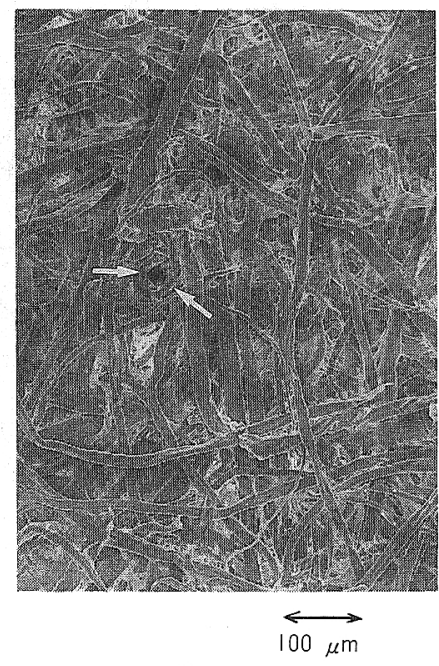

$180 \mathrm{~min}$.

Fig. 5 Scanning electron micrograph of Whatman No. 1 filter paper corona-treated for 0 min., 90 min. and $180 \mathrm{~min}$.

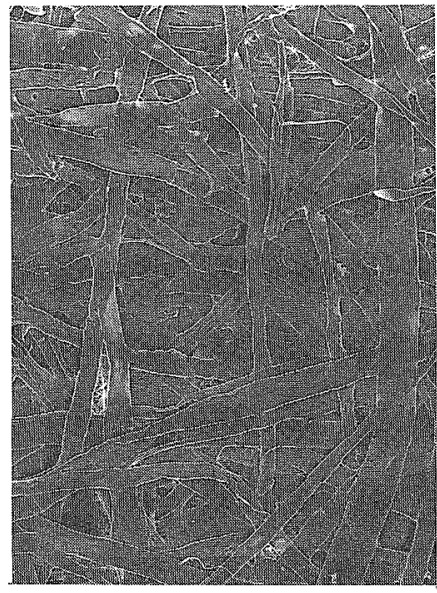

Duration :

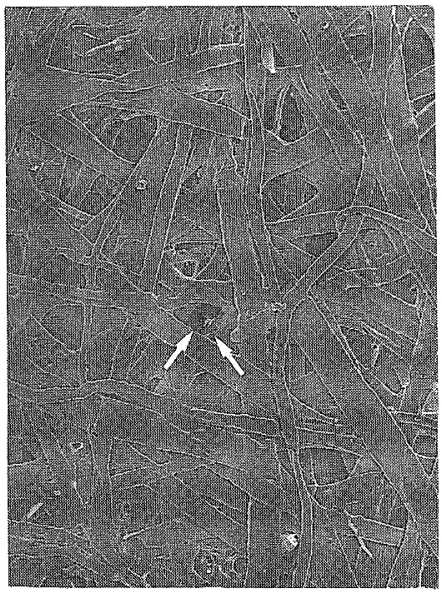

$90 \mathrm{~min}$.

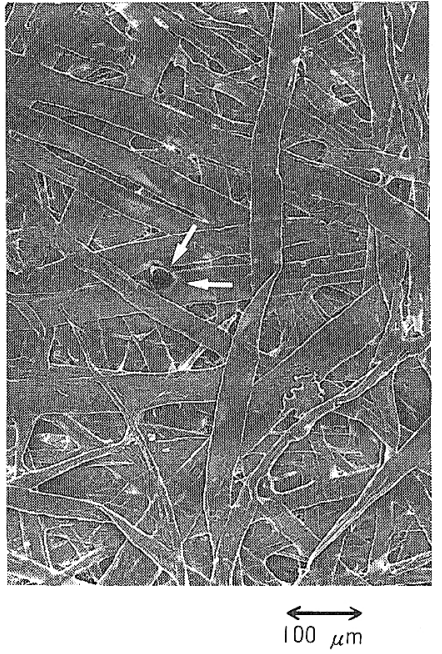

$180 \mathrm{~min}$

Fig. 6 Scanning electron micrograph of NBKP handsheet corona-treated for 0 min., 90 min. and 180 $\min$.

分の数の増加によって強度低下がもたらされた ${ }^{15,16)}$ ではないかと考えられた。

従って次に欠陌部分の特性化を行うために次の 3.3 において細孔分布の变化を検討した。

\section{3 水銀ポロシメータによる細孔分布の変化の} 検討

水銀ポロシメー夕を使用して，コロナ処理による シートの多孔性の変化について検討をおこなった。図
12 にワットマン No. 1 濾紙の圧入容積の変化を図 13 に，細孔分布の变化を表 8 に中央值で表した平均細孔 半径並びに空隙率の変化によって示す。平均細孔径が 放電処理によって增加することが分り，また多孔度が 増加することが分る。しかしこの際シート密度の変化 が小さいことは興味深い(図 14)。

\section{4 透気度による多孔性の変化の検討}

図 15 にコロナ処理時間の增加に伴う各試料シート 


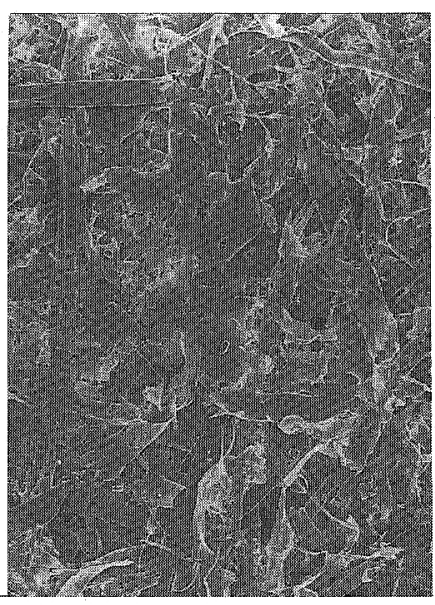

Duration:

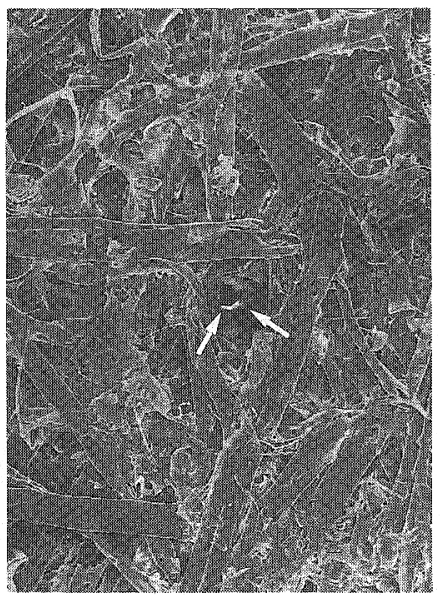

$90 \mathrm{~min}$.

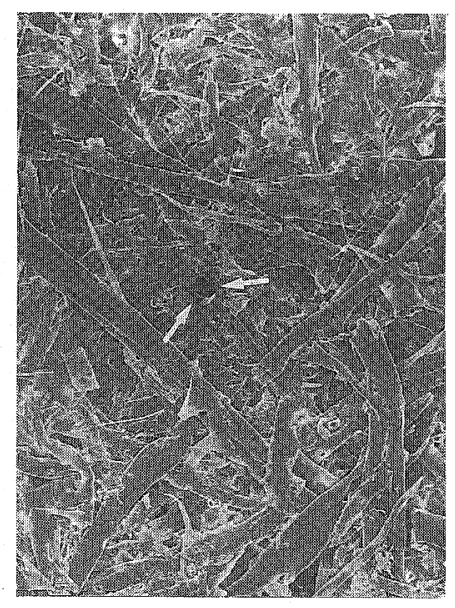

$\underset{100 \mu \mathrm{m}}{\rightleftarrows}$

180 min. 11

Fig. 7 Scanning electron micrograph of TMP handsheet corona-treated for 0 min., 90 min. and 180 $\min$.

Table 2 Appearance of boring on the cellulose sheets by the increase in the duration of corona discharge treatment.

\begin{tabular}{l|c|c|c|c|c|c}
\hline Duration(min.) & 0 & 30 & 60 & 90 & 120 & 180 \\
\hline Whatman No.1 Filter Paper & $\times$ & $\times$ & $\triangle$ & $\bigcirc$ & $\bigcirc$ & $\bigcirc$ \\
\hline Handsheet from NBKP & $\times$ & $\triangle$ & $\bigcirc$ & $\bigcirc$ & $\bigcirc$ & $\bigcirc$ \\
\hline Handsheet from TMP & $\times$ & $\bigcirc$ & $\bigcirc$ & $\bigcirc$ & $\bigcirc$ & $\bigcirc$ \\
\hline Regenerated Cellulose Film & $\times$ & $\times$ & $\times$ & $\times$ & $\times$ & $\times$ \\
\hline
\end{tabular}

$x$ : No Change, $\triangle$ : Partial Change, $\bigcirc$ : Significant Appearance

Table 3 Change in physical properties of NBKP handsheet by the progress of corona discharge treatment.

\begin{tabular}{l|cccccccccc}
\hline $\begin{array}{c}\text { Duration of Corona } \\
\text { Treatment }(\mathrm{min} .)\end{array}$ & 0 & 1 & 5 & 10 & 20 & 30 & 60 & 90 & 120 & 180 \\
\hline Basis Weight $\left(\mathrm{g} / \mathrm{m}^{2}\right)$ & 57.6 & 59.0 & 58.1 & 59.5 & 58.4 & 59.1 & 56.7 & 59.7 & 58.7 & 58.7 \\
\hline Caliper $(\mathrm{mm})$ & 0.082 & 0.088 & 0.088 & 0.089 & 0.089 & 0.089 & 0.086 & 0.087 & 0.089 & 0.091 \\
\hline Density $\left(\mathrm{g} / \mathrm{cm}^{3}\right)$ & 0.70 & 0.67 & 0.66 & 0.67 & 0.66 & 0.66 & 0.66 & 0.69 & 0.66 & 0.64 \\
\hline Tensile Index $(\mathrm{N} \cdot \mathrm{m} / \mathrm{g})$ & 78.7 & 77.2 & 78.0 & 75.8 & 75.4 & 74.2 & 74.1 & 71.7 & 72.1 & 67.6 \\
\hline $\begin{array}{l}\text { Young's Modulus }\left(\times 10^{9} \mathrm{~Pa}\right) \\
\text { Initial Modulus) }\end{array}$ & 3.62 & 3.54 & 3.54 & 3.39 & 3.31 & 3.29 & 3.19 & 3.00 & 3.00 & 2.78 \\
\hline Elongation $(\%)$ & 4.23 & 4.73 & 4.54 & 4.41 & 4.43 & 4.44 & 4.74 & 4.81 & 4.45 & 4.58 \\
\hline Moisture Content $(\%)$ & 8.7 & 8.7 & 8.7 & 8.7 & 8.7 & 8.7 & 8.7 & 8.7 & 8.7 & 8.7 \\
\hline
\end{tabular}


Table 4 Change in physical properties of TMP handsheet by the progress of corona discharge treatment.

\begin{tabular}{l|cccccccccc}
\hline $\begin{array}{l}\text { Duration of Corona } \\
\text { Treatment (min.) }\end{array}$ & 0 & 1 & 5 & 10 & 20 & 30 & 60 & 90 & 120 & 180 \\
\hline Basis Weight $\left(\mathrm{g} / \mathrm{m}^{2}\right)$ & 60.6 & 58.4 & 59.3 & 58.7 & 58.1 & 60.6 & 58.3 & 60.0 & 58.3 & 60.1 \\
\hline Caliper $(\mathrm{mm})$ & 0.157 & 0.151 & 0.154 & 0.155 & 0.154 & 0.154 & 0.157 & 0.155 & 0.154 & 0.159 \\
\hline Density $\left(\mathrm{g} / \mathrm{cm}^{3}\right)$ & 0.39 & 0.38 & 0.39 & 0.42 & 0.41 & 0.39 & 0.42 & 0.49 & 0.41 & 0.38 \\
\hline Tensile Index $(\mathrm{N} \cdot \mathrm{m} / \mathrm{g})$ & 23.2 & 23.7 & 23.2 & 23.4 & 23.5 & 22.0 & 21.5 & 22.0 & 21.2 & 18.7 \\
\hline $\begin{array}{l}\text { Young's Modulus }\left(\times 10^{9} \mathrm{~Pa}\right) \\
\text { Initial Modulus) }\end{array}$ & 0.882 & 0.883 & 0.854 & 0.860 & 0.868 & 0.854 & 0.816 & 0.827 & 0.816 & 0.770 \\
\hline Elongation $(\%)$ & 2.04 & 1.84 & 1.88 & 1.65 & 1.60 & 1.73 & 1.83 & 1.94 & 1.68 & 1.64 \\
\hline Moisture Content $(\%)$ & 10.9 & 10.9 & 10.9 & 10.9 & 10.9 & 10.9 & 10.9 & 10.9 & 10.9 & 10.9 \\
\hline
\end{tabular}

Table 5 Change in physical properties of regenerated cellulose films (longitudinal direction) by the progress of corona discharge treatment.

\begin{tabular}{l|cccccccccc}
\hline $\begin{array}{l}\text { Duration of Corona } \\
\text { Treatment }(\mathrm{min} .)\end{array}$ & 0 & 1 & 5 & 10 & 20 & 30 & 60 & 90 & 120 & 180 \\
\hline Basis Weight $\left(\mathrm{g} / \mathrm{m}^{2}\right)$ & 38.8 & - & - & 38.8 & 39.2 & 38.9 & 38.2 & 38.8 & 38.6 & 38.1 \\
\hline Caliper $(\mathrm{mm})$ & 0.031 & - & - & 0.030 & 0.030 & 0.030 & 0.030 & 0.031 & 0.030 & 0.030 \\
\hline Density $\left(\mathrm{g} / \mathrm{cm}^{3}\right)$ & 1.25 & - & - & 1.29 & 1.31 & 1.30 & 1.27 & 1.25 & 1.29 & 1.27 \\
\hline Tensile Index $(\mathrm{N} \cdot \mathrm{m} / \mathrm{g})$ & 82.9 & - & - & 78.2 & 78.4 & 78.7 & 77.9 & 74.5 & 74.7 & 66.1 \\
\hline $\begin{array}{l}\text { Young's Modulus }\left(\times 10^{9} \mathrm{~Pa}\right) \\
\text { Initial Modulus })\end{array}$ & 5.96 & - & - & 5.94 & 5.81 & 5.71 & 5.58 & 5.38 & 5.42 & 5.23 \\
\hline Elongation $(\%)$ & 8.93 & - & - & 9.66 & 12.5 & 11.2 & 12.0 & 12.0 & 12.5 & 12.0 \\
\hline Moisture Content $(\%)$ & 11.0 & - & - & 11.0 & 11.0 & 11.0 & 11.0 & 11.0 & 11.0 & 11.0 \\
\hline
\end{tabular}

Table 6 Change in physical properties of regenerated cellulose films (cross direction) by the progress of corona discharge treatment.

\begin{tabular}{l|cccccccccc}
\hline $\begin{array}{c}\text { Duration of Corona } \\
\text { Treatment }(\mathrm{min} .)\end{array}$ & 0 & 1 & 5 & 10 & 20 & 30 & 60 & 90 & 120 & 180 \\
\hline Basis Weight $\left(\mathrm{g} / \mathrm{m}^{2}\right)$ & 38.3 & - & - & 37.9 & 37.7 & 37.6 & 38.2 & 37.5 & 37.7 & 37.6 \\
\hline Caliper $(\mathrm{mm})$ & 0.030 & - & - & 0.030 & 0.030 & 0.030 & 0.030 & 0.030 & 0.030 & 0.030 \\
\hline Density $\left(\mathrm{g} / \mathrm{cm}^{3}\right)$ & 1.28 & - & - & 1.26 & 1.26 & 1.25 & 1.27 & 1.25 & 1.30 & 1.25 \\
\hline Tensile Index $(\mathrm{N} \cdot \mathrm{m} / \mathrm{g})$ & 58.7 & - & - & 58.7 & 58.4 & 58.3 & 56.7 & 56.5 & 55.8 & 55.3 \\
\hline $\begin{array}{l}\text { Young's Modulus }\left(\times 10^{9} \mathrm{~Pa}\right) \\
\text { Initial Modulus) }\end{array}$ & 4.87 & - & - & 4.80 & 4.73 & 4.67 & 4.60 & 4.46 & 4.58 & 4.34 \\
\hline Elongation $(\%)$ & 20.9 & - & - & 21.3 & 22.0 & 26.8 & 17.4 & 22.4 & 19.3 & 17.1 \\
\hline Moisture Content $(\%)$ & 12.2 & - & - & 12.2 & 12.2 & 12.2 & 12.2 & 12.2 & 12.2 & 12.2 \\
\hline
\end{tabular}


Table 7 Change in physical properties of Whatman No.1 filter paper by the progress of corona discharge treatment. ${ }^{*}$

\begin{tabular}{l|cccccccccc}
\hline $\begin{array}{l}\text { Duration of Corona } \\
\text { Treatment (min.) }\end{array}$ & 0 & $10 \mathrm{sec}$. & 1 & 10 & 20 & 30 & 60 & 90 & 120 & 180 \\
\hline Basis Weight $\left(\mathrm{g} / \mathrm{m}^{2}\right)$ & 95.0 & 91.5 & 91.2 & 95.3 & 91.4 & 90.0 & 93.2 & 88.5 & 93.9 & 91.3 \\
\hline Caliper $(\mathrm{mm})$ & 0.182 & 0.171 & 0.177 & 0.183 & 0.171 & 0.176 & 0.179 & 0.172 & 0.178 & 0.175 \\
\hline Density $\left(\mathrm{g} / \mathrm{cm}^{3}\right)$ & 0.52 & 0.53 & 0.53 & 0.52 & 0.53 & 0.51 & 0.52 & 0.51 & 0.53 & 0.52 \\
\hline Moisture Content $(\%)$ & 6.9 & 6.6 & 6.7 & 6.9 & 6.8 & 6.5 & 6.4 & 6.4 & 6.6 & 6.4 \\
\hline
\end{tabular}

${ }^{*}:$ The data about strength properties are lacking for this filter paper.

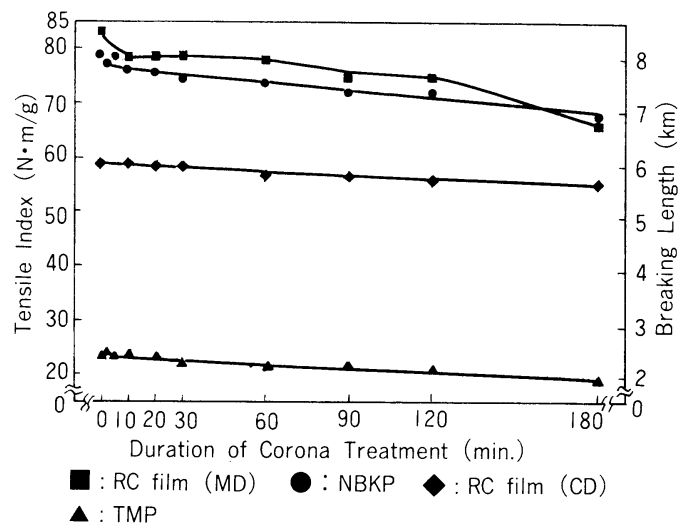

Fig. 8 The effect of duration of corona discharge treatment on tensile index or breaking length with various sheets.

$\mathrm{RC}$ : Regenerated Cellulose, MD : Machine Direction, CD : Cross direction, NBKP : Softwood Bleached Sulfate Pulp, TMP : Thermomechanical Pulp

の透気度の变化を示す。NBKP 手すき紙，TMP 手す き紙及びワットマンNo. 1 滤紙では，コロナ処理時間 が増加すると透胷性が増し透気度の值が小さくなるこ とが分る。つまり肉眼やSEM 像によって観察された のと同様に，穿孔が生じたために透気度の值が下がっ たものと考えられる。しかし，再生セルロースフィル ムでは透気度は全く変化しないことが図 15 から分り, SEM 像でも穿孔が認められなかった事実と良い一致 を示す。

\section{5 総合的考察}

0〜180分にわたつてバッチ式コロナ処理装置に よってコロナ処理をおこなうとき，セルロース繊維 シートの物性と構造がどの様に変化するかを検討した。 その結果, コロナ放電処理時間の增加によってシート

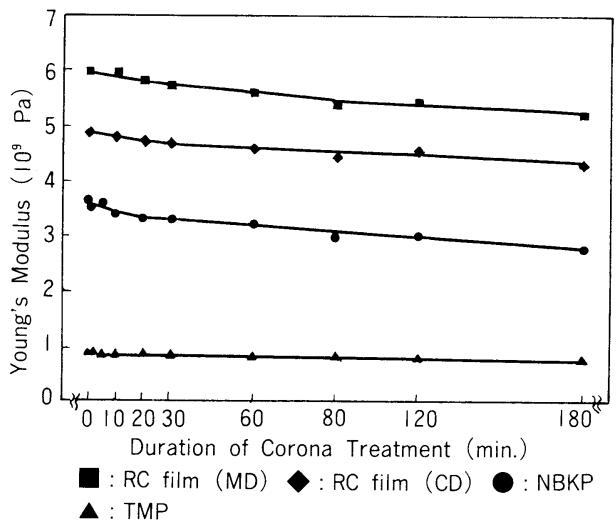

Fig. 9 The effect of duration of corona discharge treatment on Young's modulus of various sheets.

$\mathrm{RC}:$ Regenerated Cellulose, MD : Machine Direction, CD : Cross direction, NBKP : Softwood Bleached Sulfate Pulp, TMP: Thermomechanical Pulp

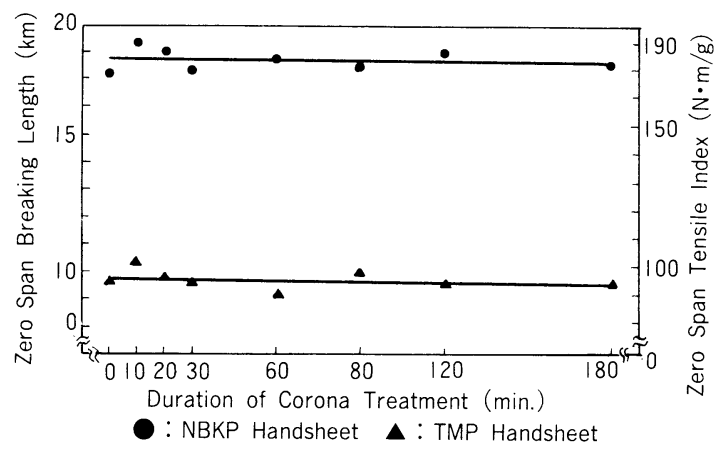

Fig. 10 The effect of duration of corona discharge treatment on zero span breaking length of the sheets. 


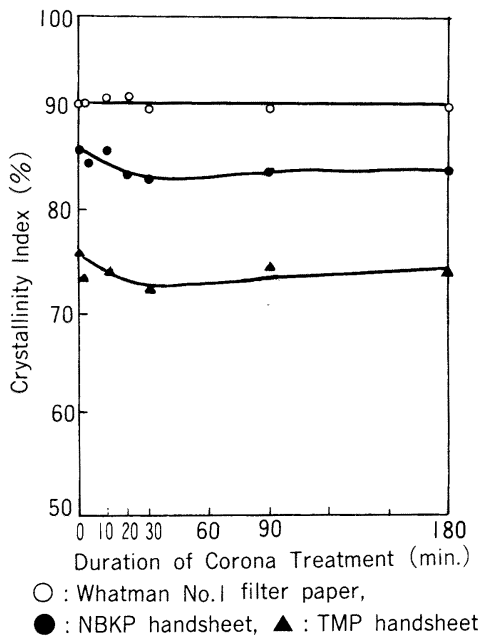

Fig. 11 Change in crystallinity index* of the cellulose fibre sheet by the increase in duration of corona treatment.

*: The crystallinity index is calculated from X-ray diffractogram by L. Segal's method $^{17)}$ which is adaptable to native cellulose.

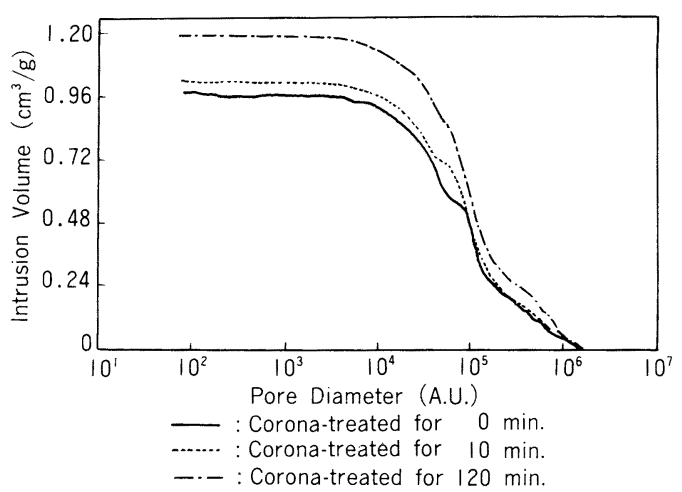

Fig. 12 Mercury intrusion curves of Whatman No. 1 filter paper.
の引張り強さやヤング係数は緩やかではあるが確実に 減少した。また繊維シートの処理面を SEMによって 観察すると，シートの種類によって若干異なるが，処 理時間が 30 分から 60 分になると穿孔を生じ, 放電処 理時間が更に増加するとその半径や個数が増加する傾 向があった。このことは, 水銀ポロシメー夕から得た 多孔度の増加と平均細孔半径の増加や透気性の増加と

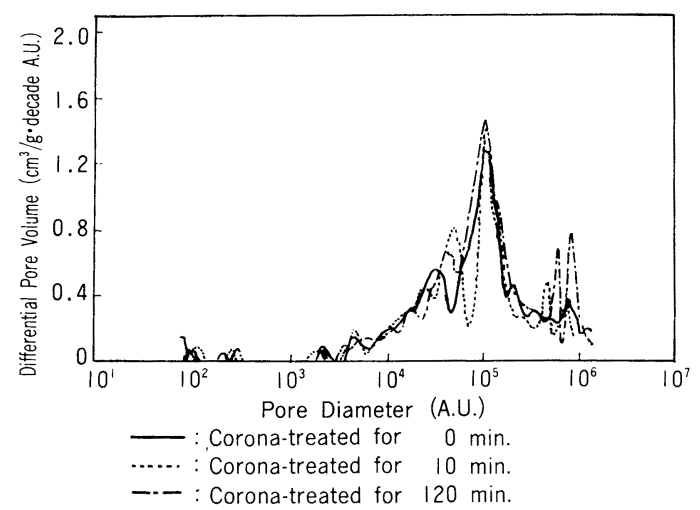

Fig. 13 Pore distribution of Whatman No. 1 filter paper.

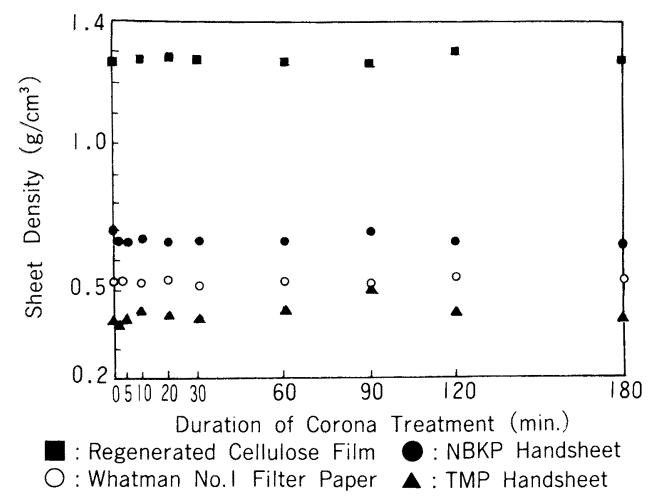

Fig. 14 Effect of duration of corona treatment on sheet density.

Table 8 Median $(\mu \mathrm{m})$ and air fraction (\%) calculated from the mercury intrusion curve for Whatman No. 1 filter paper with various duration of corona treatment.

\begin{tabular}{r|r|r|r|r|r}
\hline $\begin{array}{r}\text { Duration } \\
(\mathrm{sec} .)\end{array}$ & \multicolumn{1}{c|}{0} & 10 & 600 & 7,200 & 10,800 \\
\hline Median $(\mu \mathrm{m})$ & 9.2 & 8.0 & 9.3 & 9.5 & 17.0 \\
\hline Air Fraction $(\%)$ & 39.9 & 48.0 & 41.5 & 49.8 & 51.2 \\
\hline
\end{tabular}




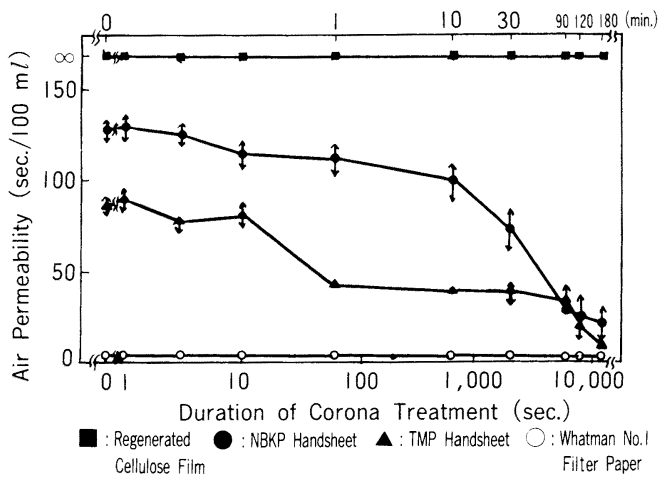

Fig. 15 Relationship between air permeability and duration of corona treatment with various cellulose sheets. Air permeability was measured by Gurley type densometer (Oken -shiki).

言った変化とも良い一致を示していた。以上のことか ら，処理時間の增加に伴うシート強度の減少は，一つ には穿孔による久陥部分の寸法の増大と欠陥部分の数 の增加によって起こるものと考えられた。

また，シート密度や吸着水分はコロナ処理時間の増 加によって殁ど变化しないが, X線回折図から得な結 晶化度が NBKP 手すき紙や TMP 手すき紙の場合, 僅かに減少して一定となることは興味深い。コロナ処 理によって SEMによって見える程度の大きさの欠陥 を生じる過程と結晶化度が僅かに減少する過程がある ことを示している。後者の過程はシートに力を加える 時，外力に対して抵抗するより微視的な範囲の骨格部 分の一部を酸化によって切断することなどの劣化過程 を含むものと考えられる。この様に考えると，再生セ ルロースフィルムの場合, コロナ处理の進行によって 穿孔が見られず透気度も变化しないにもかかわらず強 度低下が見られる事実（図 8，9）を説明出来る。

シートの強度低下についての上述の 2 つの機構の重 みに関しては，現在のところそれを判断する根拠が充 分になく更に論ずることは出来ない。

なお，ポリオレフィンラミネーションのための前処 理に用いる放電エネルギーは $5 \mathrm{~kJ} / \mathrm{m}^{2}$ 程度であり ${ }^{18)}$, ここでおこなった処理に比較して極めて小さく処理時 間として出力を $401 \mathrm{~W} / \mathrm{m}^{2}$ として計算すると, 本実験 で使用した装置においては僅か 12.5 秒の放電処理に しか相当しない。一方, 60 分の処理は $401 \mathrm{~W} / \mathrm{m}^{2}$ とし て計算すると $1,444 \mathrm{~kJ} / \mathrm{m}^{2}$ で現実の処理エネルギー より压倒的に大きい。当初期待した様に放電条件を放 電を受ける基材であるシート物性の側から捉える試み
は，現実の操業条件の 300 倍程度の放電エネルギーを 与えてもシート物性の変化が大きくなかったと言う事 実によって大きい意味を持たないことが分った。表面 改質のための前処理としてコロナ処理は，シートのバ ルクとしての物性はほとんど変化させないものと考え られる。従って現実の紙匹に対するコロナ処理は，少 なくともここで検討したシート物性には殁ど変化を与

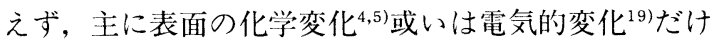
を与えるものと考えられた。

\section{4. 結 論}

ワットマン No. 1 濾紙，NBKP 手すき紙，TMP 手 すき紙及び再生セルロースフィルムを $401 \mathrm{~W} / \mathrm{m}^{2}$ の 出力で種々の時間コロナ放電処理して SEM 像の変化, シート強度の变化及び多孔度と透気度の変化などを調 べ検討した。その結果，次のことが判明した。

（1）コロナ処理時間が増加するとワットマン滤紙, NBKP 手すき紙, 及び TMP 手すき紙の処理面の SEM 像に変化が現れ，コロナ放電処理時間が 30 分から 60 分以上になると直径 $10 \mu \mathrm{m}$ から $20 \mu \mathrm{m}$ 程度の穿孔が生じることを観察した。しかし再生 セルロースフィルムについては，コロナ処理時間 の増加に伴う SEM 像の変化はなく穿孔も認めら れなかった。

（2）シートの比引張り強さ及びヤング係数は，コロ 十処理時間の増大によって緩やかに減少した。こ の傾向は SEM 像に変化のなかった再生セルロー スフィルムについても認められた。このとき，ゼ ロスパン強さも極く僅かながら減少する傾向が あった。X 線回折図から得な結晶化指数は，コ口 十処理時間の増加に伴って僅かに減少してから一 定になる試料と，ほとんど変化しない試料があっ たが変化率は小さかった。

（3）コロナ処理時間の増加によってセルロース繊維 シートは透気性を增し，水銀ポロシメー夕により 求めた多孔度も増加し，中央值として表わした平 均細孔半径も大きくなった。しかし再生セルロー スフィルムについては透気性の変化は認められな かった。

以上の諸事実は，一つにはコロナ放電によりセル ロース繊維シートに生じた直径 10 20 $\mu \mathrm{m}$ 程度の細 孔が久陥部分となり，それらのセルロース繊維シート の強度低下をもたらすものと考えると説明出来た。

また再生セルロースフィルムのコロナ処理による強 度低下には，再生セルロースに穿孔が認められず透気 度の変化も無いことから，フィルム中の微視的な骨格 
部分の一部が酸化によって切断する過程が関与するも のと推察した。

従ってセルロースシートのコロナ放電による強度低 下には，比較的巨視的に見て認められる穿孔並びに酸 化による微視的部分の劣化の両者が関わっているもの と考えられた。しかしこの二つの機構の重みについて は現在のところ評価し難い。

\section{謝 辞}

本研究をおこなうにあたり，紙のスパーク放電によ る穿孔について貴重なご示唆を戴いた神奈川大学理学 部応用科学科 門屋 卓教授, 並びにセルロース繊維 シートの多孔性に関して貴重なご示唆を戴いた三島製 紙(侏) 原 啓志氏及び同社 高野晃義氏に厚く御礼申 し上げます。また予備実験の一部を担当して戴いた末 武秀太氏並びに透気度の測定にご協力を賜りました山 陽国策パルプ(䊂商品開発研究所 吉村次郎氏に厚く御 礼を申し上げます。

\section{文献}

1) R. H. Cramm, "Pulp and Paper Vol. IV" (Ed. by J. P. Casey), p. 2530-2531, Wiley-Interscience, N. Y. (1983)

2) D. A. I. Goring, Pulp \& Paper Mag. of Can. 68, T 372-376 (1967)

3) G. Suranyi, D. G. Gray and D. A. I. Goring, Tappi, 63 ( 4 ), 153-154 (1980)

4) A. Sawatari, Y. Hayashi and T. Kurihara, "CELLULOSE-structural and functional aspects" (Ed. by J. F. Kennedy, G. O. Phillips and P. A. Williams), p. 137-142 (1989), Ellis Horwood Ltd, Chichester

5) A. Sawatari and H. Nakamura, J. Soc. Fiber
Sci. \& Technol. Japan.,[to be published on June in 1993, as 49 (6), (1993)] ; Cellcon '90 Abstract, p. 73 (1990)

6）森田義博, 坂田 功, 繊維学会誌, 43(9), 85(1987)

7) I. Sakata and D. A. I. Goring, J. Appl. Polym. Sci., 20, 574 (1976)

8) M. Stradal and D. A. I. Goring, Polym. Eng. Sci., 17 ( 1 ), 39 (1977)

9) P. Blais, D. J. Carsson and D. M. Wiles, J. Appl. Polym. Sci., 15, 129 (1971)

10) J. F. Carley and P. T. Kitze, Polym. Eng. Sci., 18 ( 4 ), 326-334 (1978)

11）張 恒雄, 村上浩二, 今村力造, 材料, 26 (284), 477 -481 (1977)

12）絶縁照射専門委員会編：電気学会技術報告（I 部) 第 74 号 (1966)

13）新田：電気絶縁材料の化学，150-156，焙風館 (1983)

14）門屋 卓：「天然紙質の力学的挙動に関する研 究」, pp. 58-90, 東北大学博士学位論文 (1971) ; 私 信

15）横堀武夫：材料強度学, 技報堂, p. 74, p. 82 (1973)

16）横堀武夫：材料強度学, 岩波書店, p. 106 (1963)

17) L. Segal, J. J. Greely, A. E. Martin Jr. and C. M. Conrad, Text. Res. J., 29, 786 (1959)

18) E. L. Back and S. Danielsson, Proc. 4 th. ISWPC, p. 109-120 (1987)

19) D. A. I. Goring, "The Fundamental Properties of Paper Related to Its Uses", Vol, I. p. 172-189, Ernest Benn Ltd., London (1976)

(受理 : '92.9.20) 